\title{
ANALISIS PENGARUH PERPUTARAN KAS, PERPUTARAN PERSEDIAAN, PERPUTARAN PIUTANG TERHADAP TINGKAT LABA SERTA DAMPAKNYA TERHADAP HARGA SAHAM (Studi Terhadap Perusahaan Otomotif pada Malaysia Exchange Stock Tahun 2011-2016)
}

\author{
Saksono Budi \\ Fakultas Ekonomi, Universitas Pamulang \\ dosen02310@unpam.ac.id
}

\begin{abstract}
This study aims to analyze the effect of cash turnover, inventory turnover, receivable turnover to profit rate and its impact on stock prices at automotive companies listed on the Malaysia Stock Exchange. The population in this study finished 10 registered compananies on the Malaysian ExchangeStock period 2011-2016. In this research obtained finished 5 (five) companies determined as sample, companies that were used as samples taken using purposive sampling method,. Statistical testimg is done using regression test of panel data of random effect Eviews 9.0 model. this research method uses descriptivequantitative by doing the activity of collecting secondary data from company annual report. Cash turnover, inventory turnover, receivable turnover as independent variable, and net profit as moderating variable. While stock price is measured by Change of stock price. The results showed that simultaneously, variable cash turnover, inventory turnover and receivable turnover significantly affect the level of earnings. Partially, inventory turnover and receivable turnover have a positive and significant influence to profit rate but cash turnover variable has negative and significant influence to profit rate. While the level of profit has a positive and significant effect on stock prices.
\end{abstract}

Keywords: Cash Turn Over, Inventory Turn Over, Receivables Turn Over, Profit Rate, Stock Price.

\section{PENDAHULUAN}

Untuk menunjang kelangsungan eksistensi usahanya semua perusahaan tentunya membutuhkan modal kerja yang dipakai untuk membiayai operasional perusahaan dari penyediaan bahan baku, biaya administrasi bahkan sampai pengembangan usahanya. Melihat pentingnya modal kerja bagi suatu perusahaan secara tidak langsung semua perusahaan menaruh perhatian yang besar terhadap modal kerja ini dengan harapan modal kerjanya bermanfaat secara efisien dan efektif dan pada akhirnya akan berpengaruh terhadap laba 
perusahaan dan harga sahamnya. Beberapa bagian dari modal kerja diantaranya kas, persediaan, piutang dan lain sebagainya.

Pada penelitian ini fokus pada pengaruh perputaran kas, perputaran persediaan, perputaran piutang terhadap tingkat laba serta dampaknya terhadap harga saham pada indeks manufaktur sub sektor otomotif pada malaysia exchange stock. Perusahaan manufaktur khususnya pada bidangautomotif dipilih sebagai sampel penelitian itu dikarenakan perusahaan $\mathrm{mr}$ anufaktsub sektor otomotif yang mendominasi sebagian besar perusahaan manufaktur. Itu semua bisa dilihat dari seiring berkembangnya pertumbuhan perekonomian nasional dan industri otomotif merupakan penyumbang terbesar dari pertumbuhan tersebut. Semakin besarnya tingkat permintaan terhadap produk otomotif tersebut dapat terlihat dari meningkatnya permintaan masyarakat akan produk otomotif setiap tahunnya. Seiring meningkatnya permintaan konsumen terhadap produk produk otomotif maka dari setiap pelaku usaha dibidang otomotif harus memiliki kemampuan manajemen yang baik untuk tetap menjaga kualitas akan produk yang dihasilkan dan juga harus memiliki kemampuan manajemen modal kerja demi kelangsungan perusahaan dimasa yang akan datang.

Data keuangan yang tersaji dari 5 (Lima) perusahaan sebagai berikut:

Tabel 1. 1

Perputaran Modal Ke rja

\begin{tabular}{|c|c|c|c|c|c|c|c|c|c|}
\hline \multirow{2}{*}{ Perusahaan } & \multicolumn{3}{|c|}{2011} & \multicolumn{3}{|c|}{2012} & \multicolumn{3}{|c|}{2013} \\
\hline & $\mathbf{x 1}$ & $\mathbf{x} 2$ & $\mathbf{x} 3$ & $\mathbf{x 1}$ & $\mathbf{x 2}$ & $\mathbf{x} 3$ & $\mathbf{x 1}$ & $\mathbf{x} 2$ & $\mathbf{x} 3$ \\
\hline SOLID AUTOMOTIVE BHD & 15,82 & 2,11 & 4,77 & 15,61 & 2,05 & 4,78 & 15,75 & 1,90 & 4,73 \\
\hline APM AUTOMOTIV BHD & 3,17 & 5,38 & 5,84 & 2,92 & 5,61 & 5,47 & 3,43 & 4,89 & 4,98 \\
\hline BERMAZ AUTO BHD & 16,91 & 5,66 & 29,20 & 22,11 & 5,47 & 21,57 & 24,87 & 5,16 & 25,39 \\
\hline UMW BHD & 6,14 & 6,97 & 11,87 & 6,72 & 6,92 & 11,70 & 5,53 & 5,38 & 8,24 \\
\hline CHINA AUTOMOBILE BHD & 3,47 & 28,87 & 12,40 & 3,43 & 36,34 & 6,20 & 2,59 & 36,98 & 5,90 \\
\hline
\end{tabular}




\begin{tabular}{|c|c|c|c|c|c|c|c|c|c|}
\hline \multirow{2}{*}{ Perusahaan } & \multicolumn{3}{|c|}{2014} & \multicolumn{3}{|c|}{2015} & \multicolumn{3}{|c|}{2016} \\
\hline & $\mathrm{X} 1$ & $\mathrm{X} 2$ & X3 & $\mathrm{X} 1$ & $\mathrm{x} 2$ & X3 & $\mathrm{x} 1$ & $\mathrm{x} 2$ & X3 \\
\hline SOLID AUTOMOTIVE BHD & 19,78 & 1,93 & 4,24 & 19,60 & 2,21 & 4,26 & 11,95 & 2,00 & 3,90 \\
\hline APM AUTOMOTIV BHD & 4,19 & 4,58 & 4,39 & 4,24 & 4,46 & 4,68 & 5,01 & 4,55 & 5,40 \\
\hline BERMAZ AUTO BHD & 30,62 & 4,92 & 30,31 & 25,58 & 5,53 & 24,15 & 19,01 & 6,32 & 21,91 \\
\hline UMW BHD & 5,04 & 5,75 & 7,59 & 4,73 & 5,59 & 7,38 & 4,77 & 4,24 & 7,77 \\
\hline CHINA AUTOMOBILE BHD & 1,76 & 32,53 & 4,43 & 1,36 & 31,58 & 2,47 & 1,75 & 34,25 & 2,49 \\
\hline
\end{tabular}

Tabel 1. 2

Data Tingkat Laba dan Harga Saham

\begin{tabular}{|l|r|r|r|r|r|r|}
\hline \multirow{2}{*}{\multicolumn{1}{c|}{ Perusahaan }} & \multicolumn{2}{c|}{$\mathbf{2 0 1 1}$} & \multicolumn{2}{c|}{$\mathbf{2 0 1 2}$} & \multicolumn{2}{c|}{$\mathbf{2 0 1 3}$} \\
\cline { 2 - 8 } & \multicolumn{1}{c|}{$\mathbf{Y}$} & \multicolumn{1}{c|}{$\mathbf{Y}$} & \multicolumn{1}{c|}{$\mathbf{Z}$} & \multicolumn{1}{c|}{$\mathbf{~}$} & \multicolumn{1}{c|}{$\mathbf{Z}$} \\
\hline SOLID AUTOMOTIVE BHD & 6.323 & 0,60 & 7.710 & 0,62 & 9.403 & 0,65 \\
\hline APM AUTOMOTIV BHD & 135.884 & 4,45 & 125.187 & 4,71 & 141.369 & 5,79 \\
\hline BERMAZ AUTO BHD & 37.579 & 1,25 & 44.211 & 1,30 & 52.013 & 1,32 \\
\hline UMW BHD & 969.513 & 6,33 & 1.588 .807 & 11,03 & 1.084 .212 & 11,12 \\
\hline CHINA AUTOMOBILE BHD & 114.243 & 1,86 & 131.314 & 1,96 & 141.382 & 2,39 \\
\hline
\end{tabular}

\begin{tabular}{|l|r|r|r|r|r|r|}
\hline \multirow{2}{*}{ Perusahaan } & \multicolumn{2}{c|}{$\mathbf{2 0 1 4}$} & \multicolumn{2}{c|}{$\mathbf{2 0 1 5}$} & \multicolumn{2}{c|}{$\mathbf{2 0 1 6}$} \\
\cline { 2 - 8 } & \multicolumn{1}{c|}{$\mathbf{Y}$} & \multicolumn{1}{c|}{$\mathbf{Y}$} & \multicolumn{1}{c|}{$\mathbf{~}$} & \multicolumn{1}{c|}{$\mathbf{Z}$} & \multicolumn{1}{c|}{$\mathbf{~}$} & \multicolumn{1}{c|}{} \\
\hline SOLID AUTOMOTIVE BHD & 7.446 & 1,64 & 9.494 & 1,39 & 5.561 & 1,34 \\
\hline APM AUTOMOTIV BHD & 111.152 & 4,84 & 71.913 & 3,85 & 59.371 & 3,46 \\
\hline BERMAZ AUTO BHD & 133.848 & 3,31 & 219.485 & 2,17 & 210.360 & 2,10 \\
\hline UMW BHD & 1.213 .005 & 10,13 & 2.192 & 7,27 & $(2.269 .777)$ & 4,22 \\
\hline CHINA AUTOMOBILE BHD & 137.233 & 3 & 65.541 & 2,74 & 76.683 & 2,49 \\
\hline
\end{tabular}

Sumber : Data prariset Industri Otomotif Bursa Malaysia (2017)

Dari hasil pengamatan uraian tersebut, ada ketertarikan penulis untuk melakukan analisis penelitian dengan judul "ANALISIS PENGARUH PERPUTARAN KAS, PERPUTARAN PERSEDIAAN, PERPUTARAN PIUTANG, TERHADAP TINGKAT LABA SERTA DAMPAKNYA TERHADAP HARGA SAHAM" (Studi terhadap perusahaan manufaktur sub sektor otomotif pada Malaysia Stock Exchange periode 2011-2016). 


\section{TELAAH LITERATUR DAN PENGEMBANGAN HIPOTESIS}

\section{Pengertian Manajemen}

Manajemen merupakan suatu proses planning, organizing, actualing and controlling yang sering disebut dengan istilah POAC untuk mencapai suatu tujuan tertentu. Pada umumnya manajemen diartikan sebagai suatu proses perencanaan, pengorganisasian pelaksanaan dan pengontrolan suatu kegiatan atau aktivitas organisasi untuk menjalankan misi organisasi dengan harapan mewujudkan visi organisasi.

\section{Pengertian Manajemen Keuangan}

Beberapa ahli menyimpulkan bahwa manajemen keuangan dapat disimpulkan sebagai salah satu aktivitas yang dilakukan oleh sebuah organisasi ataupun perusahaan untuk merencankan, mengatur dan mengarahkan sertamengawasi aktifitas keuangan organisasi ataupun perusahaan tersebut yang tujuan utamanya adalah meastikan kesejahteraan para investor ataupun pemegang saham secara maksimal.

Selain itu manajemen keuangan juga memiliki fungsi untuk melakukan serangkaian aktifitas yang berhubungan dengan cara bagaimana organisasi atau perusahaan tersebut agar dapat memperoleh sumber pendanaan yang nantinya akan digunakan untuk membiayai operasional organisasi ataupun perusahaan tersebut untuk mewujudkan visinya.Tujuan manajemen keuangan menurut beberapa literasi yang dibaca penulis, ada beeberapa diantaranaya adalah untuk memaksimalkan keuntungan melalui keputusan-keputusan yang tepat sehingga keuntungan yang didapat bisa maksimal. Selain memaksimalkan keuntungan tujuan dari manajemen keuangan adalah menjaga supaya arus kas yang terjadi diperusahaan sudah sesuai dengan perencanaan yang sudah dianggarkan sebelumnya, sehingga semua kewajiban dan beban perusahaan bisa terbayarkan dengan kas yang ada. Tujuan manajemen keuangan selanjutnya adalah pengumpulan sumber dana yang akan digunakan sebagai modal kerja, sumber dana yang didapat bisa dari internal perusahaan maupun eksteral perusahaan. Setelah dana di dapat tujuan dari manajemen keuangan adalah memanfaatkan 
dana tersebut sebagai modal kerja untuk dapat di manfaatkan secara tepat dan optimal agar penggunaan modal kerja tersebut efisien dan tepat sasaran. Dan tujuan manajemen keuangan yang terakhir adalah memaksimalkan kekayaan perusahaan untuk menjamin kesejahteraan para investor ataupun pemegang saham.

Adapun fungsi manajemen menurut beberapa ahli yang menyatakan fungsi dari manajemen keuangan yang diantaranaya meliputi perencanaan penggaran, kontrol dan pelaporan. Yang pertama yaitu perencanaan, perencanaan disini adalah merencanakan keuangan perusahaan atau organisasi dari menyusun cas flow perusahaan sampai menyusun laporan laba rugi perusahaan. Yang kedua yaitu penggaran, penganggaran disini berfungi untuk melakukan perencanaan sampai mengalokasikan anggaran yang sudah di rencanakan supaya lebih efisien sehingga bisa mencapai tujuan yang sudah ditetapkan. Selanjutnya yang ketiga adalah kontrol, dalam pengelolaankeuangan biasanya banyak celah untuk melakukan kecurangan-kecurangan yang akan mengakibatkan kerugian bagi perusahaan tersebut, disinilah fungsi kontrol untuk melakukan pengawasan supaya hal-hal tersebut tidak terjadi di dalam pelaksanaannya. Dan yang terakhir adalah adalah pelaporan, pelaporan disini adalah melaporkan kondisi keuangan perusahaan yang nantinya akan digunakan untuk pengambilan keputusan dalam pembagian deviden kepada investor.

\section{Definisi Laporan Tahunan}

Laporan tahunan atau yang sering disebut dengan laporan keuangan adalah laporan yang menyajikan empat laporan keuangan dasar, yaitu:laporan posisi keuangan atau yang dahulu disebut sebagai laporan neraca, merupakan bagian dari laporan keuangan suatu perusahaan yang terdapat informasi mengenai aktiva, kewajiban, serta ekuitas perusahaan pada akhir periode akuntansi perusahaan tersebut. Namun dalam Pernyataan Standart Akuntansi Keuangan (PSAK) merevisi neraca menjadi Laporan Posisi Keuangan. Yang kedua Laporan laba rugi (Income Statement), merupakan laporan yang menginformasikan keuntungan atau ruginya suatu perusahaan yang disanding dari pendapatan dengan beban yang 
terjadi selama satu periode. Yang selanjutnya ada laporan laba ditahan (Statement of Retained Earnings), laba dari operasi yang dibagikan dan menjadi tambahan penyertaan perusahaan. Karena biasanya uang ini kembali diinvestasikan kedalam perusahaan yang akan digunakan untuk membiayai operasional perusahaan untuk membayar kewajiban jangka pendek maupun kewajiban jangka panjang. Dan yang terakhir (Cash Flow), atau yang sering disebit dengan laporan arus kas adalah laporan keuangan yang berisi tentang keluar dan masuknya kas didalam suatu perusahan dalam suatu periode. Cash flow atau laporan arus kas itu sendiri terdiri dari 3 tiga aktifitas, yang pertama laporan arus kas yang berkaitan dengan aktifitas operasional, dalam aktifitas ini mencatat keluar masuknya kas perusahaan yang dipakai untuk membiayai operasional perusahaan seperti biaya gaji karyawan, biaya administrasi, biaya listrik, telpon, air dan lain sebagainya yang intinya itu untuk membiayai operasional perusahaan. Aktifitas yang kedua di dalam cash flow atau laporan arus kas adalah aktifitas yang berkaitan dengan investasi, aktifitas ini mencatat keluar dan masuknya kas pada perusahaan yang berkaitan dengan investasi perusahaan, misalnya ketika ada pembelian dan penjualan aktiva tetap seperti beli tanah, kendaraan, mesin dan lain sebagainya. Dan aktifitas yang ketiga yang terdapat dalam cash flow adalah aktifitas pendanaan, dimana laporan ini akan mencatat keluar dan masuknya yang kas yan berkaitan dengan pendanaan misalnya seperti peneribitan dan pembelian saham, pengakuisisian perusahaan lain dan lain sebagainya.

\section{Pengertian Modal}

Menurut beberapa ahli dan literasi yang penulis baca, penulis dapat menyimpulkan bahwa modal adalah sejumlah sumberdaya yang dimiliki suatu organisasi atau perusahaan yang bisa digunakan untuk membiayai kegiatan operasional perusahaan. Karena modal merupakan salah satu aset utama perusahaan untuk membiayai keperluan operasionalya sehingga perusahaan tersebut menghasilkan keuntungan.. Contoh perusahaan dalam menggunakan modal awalnya, ketika perusahaan ingin membuka usahanya tentu saja perusahaan membutuhkan tempat usaha, dan alat alat lainnya untuk melakukan proses 
produksi. Lalu setelah semuanya didapat, modal tersebut akan dipakai untuk membiayai proses produksi. Yakni seperti pengadaan bahan baku, bahan pembantu atau bahan lainnya sehingga terbentuklah barang yang akan di pasarkan oleh pemasaran untuk mendapatkan laba. Dan terakhir modal untuk membiayai administrasi perusahaan yang di gunakan untuk gaji pegawai serta digunakan untuk membiayai operasional perusahaan. Contohnya seperti listrik, telepon, dan lain-lainya.

\section{Pembagian Modal}

Pada dasarnya modaldilihat dari neraca sebuah perusahaan dibedakan menjadi dua, modal aktif dan modal pasif. Modal aktif itu sendiri yaitu modal yang dipakai untuk membiayai semua kebutuhan perusahaan yang bersifat wujud atau bisa dilihat oleh kasat mata, baik digunakan untuk membangun perusahaan maupun operasionalnya.Misalnya persediaan (bahan baku, bahan penolong, dll), perlengkapan, peralatan, gedung, kendaraan.

Sedangkan modal pasif adalah kekayaan perusahaan untuk modal usaha yang didapat dari sumber modal. Dalam neraca perusahaan, modal pasif ini memperlihatkan posisi real akun yg berada di kredit. Adapun contoh dari modal pasif seperti modal yang berasal dari internal perusaahaan sebagai contoh investasi pemilik oleh owner dan lain sebagainya, sedangkan modal asing yaitu hasil investasi dari pihak ketiga, bisa dari bank dan lemgbaga keuangan lainnya. Biasanya modal ini memiliki tanggungan besar terhadap semua resiko. Karena, modal inilah yang akan menjadi jaminan untuk para kreditor.

\section{Modal Kerja}

Beberapa ahli menyimpulkan pengertian modal kerja diantaranya ada yang mengatakan jika modal kerja itu "keseluruhan aktiva lancar yang dimiliki perusahaan sebagai dana yang harus tersedia untuk membiayai kegiatan operasi perusahaan sehari-hari” (Agnes sawir (2005:129)). Ada juga yang menyimpulkan "Modal kerja adalah modal yang harus ada dalam perusahaan sehingga operasionalnya menjadi lebih lancar sampai akhir tujuan perusahaan untuk 
menghasilkan laba yang akan tercapai." (Sri dwi ari ambarwati (2012:112)). Selain itu ada yang mengartkan jika "Modal kerja dapat diartikan sebagai investasi yang ditanam dalam aktiva lancar atau aktiva jangka pendek, seperti kas, bank, surat-surat berharga, piutang, persediaan, dan aktiva lancar lainnya" (Kasmir : 2011:250)).

Kesimpulan dari penulis bahwasanya modal kerja adalah aset lancar yang bermanfaat untuk keberlangsungan dan pertumbuhan perusahaan dimasa yang akan datang, jika suatu perusahaan mengalami defisit modal kerja bisa jadi perusahaan tersebut akan mengalami kerugian bahkan tidak akan bertahan untuk melangsungkan operasionalnya, itu semua diakaibatkan karena perusahaan tersebut tidak mampu membayar kewajiban jangka pendeknya untuk mengatasi masalah likuiditasnya.

Dari definisi mengenaiworking capita atau modal kerja terbagi menjadi 2 (dua) yakni modal kerja kotor dan modal kerja bersih. Pertama modal kerja kotor, merupakan keseluruhan aktiva lancar. Kedua modal kerja bersih, pada umumnya aktiva lancar sendiri itu terdiri dari uang tunai atau kas, surat surat berharga, piutang dan persediaan.

Komponen modal kerja bruto yang pada umumnya disebut dengan gross working capital adalah modal kerja yang berupa kas, piutang, dan persediaan. Salah satu komponen modal kerja yang paling sering digunakan salah satunya adalah kas, kas sendiri itu digunakan untuk membiayai seluruh kegiatan operasional perusahaan maupun untuk mengadakan investasi baru dalam aktiva tetap. Adapun rasio untuk mengukur keefektifan kas bisa dilihat dari seberapa besar perputaran kas terjadi dalam suatu periode dengan menggunakan rumus seperti yang tergambar dibawah ini:

$$
\text { Rasio Perputaran Kas }=\frac{\text { Penjualan Bersih }}{\text { Rata-rata kas dan Setara kas }}
$$

Tingkat efisiensi penggunaan kas diukur dari seberapa besar kas itu berputar, sejauh ini belum ada standart yang menjadi tolak ukur berapa jumlah perputaran 
kas yang baik setiap periode, akan tetapi jika perputaran kasnya tinggi, secara otomatis penggunaan kas pada periode tersebut menjadi efisien, begitupun sebaliknya apabila tingkat perputaran kasnya rendah mengindikasikan penggunaan kasnya kurang efisien. Akan tetapi perlu dipahami juga apabila perputaran kasnya terlalu tinggi juga, karena itu berarti jumlah kas yang tersedia terlalu kecil dan itu tidak bagus untuk likuiditas perusahaan.

Selain kas, modal kerja lainnya yang tidak kalah penting adalah persediaan. Persediaan merupakan salah satu modal kerja yang penting bagi perusahaan. Hampir semua perusahaan terutama perusahaan industri pasti memerlukan persediaan yang akan dipakai untuk proses produksi. Persediaan menjadi salah satu modal kerja karena persediaan merupakan salah satu item yang menjadi dasar berjalannya suatu perusahaan terutama perusahaan industri. Untuk memastikan keberlansungan penjualan suatu perusahaan harus memiliki jumlah stok produk yang cukup, dan stok pruduk yang cukup itu tergantung dari kecukupan persediaan yang tersedian dalam gudang. Sama halnya dengan kas, persediaan juga bisa dinilai atau dihitung baik buruknya persediaan yang tersedia didalam gudang yang di hitung atau di estimasi dengan cara menghitung rasio persediaan, perhitungan rasio yang dapat digunakan untuk mengukur baik buruknya persediaan yang tersedia bisa dengan cara menghitung seberapa besar persediaan itu berputar dalam suatu periode tertentu.

Kasmir (2011:180) mengemukakan perhitungan pengukuran rasio perputara persediaan dapat dihitung dengan membagi cost of good sold dengan avareage inventori sebagaimana tergambar pada kolom dibawah ini:

$$
\text { Inventory Tum Over }=\frac{\text { Cost of Good Sold }}{\text { Avarage Iwentory }}
$$

Efektifitas penggunaan persediaan tercermin dalam skala tingkat perputaran persediaan tersebut, jika perputara persediaanya cepat, secara tidak langsung pada saat tersebut tingkat penjualannya juga bagus, itu berarti tingkat pengembalian modalnya semakin cepat. Jika tingkat persediaan dan penjualan tidak singkron 
atau tidak berjalan beriringan itu berarti adanya pengambilan kebijakan pembelian persediaan yang keliru sehingga persediaan yang dibeli menumpuk di gudang.

Selain dari kas da persediaan, yang tidak kalah penting dan yang sering menjadi ukuran modal kerja itu efektif atau tidak bagi operasional perusahaan adalah piutang. Piutang terjadi karena adanya penjualan secara kredit, apabila di dalam system pengendalian piutang tidak sesuai prosedur, maka piutang itu sendiri justru bisa mengakibatkan modal kerja pada suatu perusahaan tidak eefektif, misalnya ketika banyak piutang yang tidak dapat tertagih yang akan mengganggu likuiditas perusahaan dan lain sebagainya. Untuk itu piutang sendiri perlu di perhitungkan dan dinilai tersendiri supaya piutang yang ada terukur dan dapat membantu modal kerja menjadi lebih efektif. Karena piutang merupakan salah satu dari elemen modal kerja yang selalu mengalami perputaran yang pada ujungnya akan berpengaruh terhadap kas dan persediaan. Perputaran piutang akan sangat tergantung dengan system pengendalian piutangnya, misalanya adanya prasyarat untuk pembayarannya, jika prasyarat pembayarannya kuat itu berarti perputaran piutangnya secara otomatis akan lebih cepat, begitupun sebaliknya.

Untuk mengukur umur perputaran piutang beberapa ahli mengemukakan jika "Piutang adalah salah satu unsur modal kerja yang selalu berputar, dari kas, proses komoditi, penjualan secara kredit, timbulnya piutang, dan kembali lagi ke kas". Jika perputarannya cepat artinya kondisi keuangan perusahaan bisa dikatan bagus begitupun sebaliknya. (Darsono : 2006 : 95). Sedangkan untuk mengukur rasio perputaran piutang K. R Subramanyam (2010 : 45) mengungkapakan bahwa "Perputaran piutang dapat dihitung dengan membagi penjualan bersih dengan rata-rata piutang yang terjadi pada periode tersebut".

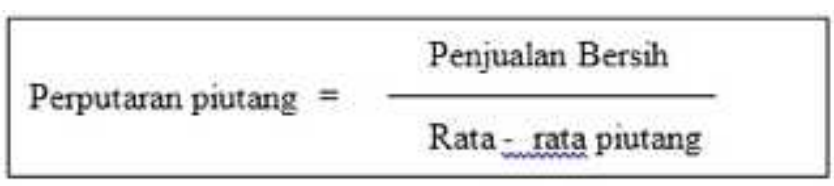




\section{METODOLOGI PENELITIAN}

\section{Sifat Penelitian}

Pada penelitian kali ini penulis akan melakukan penelitian yang bersifat kuantitatif untuk menguji dan membuktikan seberapa besar pengaruh perputaran kas, perputaran persediaan dan perputaran piutang apakah ada pengaruh variabel perputaran kas, persediaan dan piutang terhadap Tingkat laba dan apakah ada dampaknya terhadap harga saham.

\section{Unit Analisis Penelitian}

Penelitian ini dilakukan dengan menggunakan data yang diambil dari Malaysia exchange stock. Penelitian mengambil data sekunder laporan tahunan dari perusahaan manufaktur sub sector otomotif yang terdaftar di Bursamalaysia yang di unduh melalui website www.bursamalaysia.com

\section{Periode Data Penelitian}

Waktu penelitian dilakukan mulai dari semester gasaltahun akademik 2016/2017 atau bulan September s.d Desember 2016.

\section{Metode Penentuan Sampel}

Pada penelitian ini, penulis menggunakan metode penentuan sampel dengan cara melakukan mengambil data pada perusahaan manufaktur sub sektor otomotif yang terdaftar pada Bursa Malaysia untuk melakukan pengujianvariable x yang terdiri dari perputaran kas, perputaran persediaan dan perputaran piutang terhadap variabel tingkat laba sekaligus untuk melihat terhadap harga saham.

\section{Populasi Penelitian}

Populasi dalam penelitian merupakan perusahaan otomotif yang terdaftar pada Bursa Malaysia dimulai tahun 2011 s.d tahun 2016. Penelitian ini menggunakan populasi sebanyak 10 (sepuluh) perusahaan sub sektor otomotif yang diambil dari sample yang berhasil dikumpulkan penulis. 10 (sepuluh) 
menjadi menarik untuk diteliti karena perusahaan ini mempunyai tingkat labayang baik, dan tingkat laba yang baik inilah yang dijakdkan salah satu factor utama dalam meningkatkan daya saing perusahaan. Akan tetapi ada beberapa sample perusahaan pada saat publikasi tidak menyertakan elemen yang diperlukan dalam penelitian ini sehingga hanya diambil 5 (lima) perusahaan yangdijadikan sampel dalam penelitian ini.

\section{Sampel Penelitian}

Pada penelitian ini sampel yang akan digunakan adalah laporan keuangan perusahaan yang dipublikasi dari tahun 2011 sampai dengan tahun 2016. Laporan keuangan perusahaan tahun 2011 sampai 2016 dipilih penulis karena pada tahun tersebut laporan keuangannya akan menggambarkan kondisi perusahaan yang relatif uptodate. Penelitian ini sengaja menggunakan data yang relative uptodate dengan harapan dapat memberikan informasi yang relevan untuk mengetahhui konsidisi sesuai keadaan sebenarnya. Beberapa kriteria penetuan sampelnya sebagai berikut:Perusahaan otomotif yang terdaftar pada Malaysia exchange stock untuk tahun 2011 sampai tahun 2016 yang dapat diakses (tidak underconstruction) saat pengumpulan data dilakukan, perusahaan yang mempublikasikan laporan tahunan (annual report) lengkap selama tahun 2011 sampai tahun 2016.

\section{HASIL PENELITIAN DAN PEMBAHASAN}

\section{Pembahasan Hasil PenelitianPengaruh Variabel X terhadap Variabel Y}

Berdasarkan hasil penelitian yang telah dilakukan, dari perhitungan regresi data panel fixed effect selama periode pengamatan (2011-2016) menunjukkan bahwa pengaruh perputaran kas, perputaran persediaan, dan perputaran piutang terhadap tingkat laba sebagai berikut: 
Model Common Effect (CE)

Variabel Perputaran Kas, Perputaran Persediaan, Perputaran Piutang Terhadap

Variabel Tingkat Laba

Dependent Variable: Tingikat Laba

Method: Panel Least Squares

Date: 121417 Time: 20.28

Sample: 20112016

Periods included: 6

Cross-sections included: 5

Total panel (balanced) observations: 30

\begin{tabular}{ccccc}
\hline Variable & Coefficieat & Std. Error & t-Statistic & Prob. \\
\hline C & -436494.3 & 39005.42 & -11.19060 & 0.0000 \\
Perputaran Kat & -20423.43 & 5166.410 & -3.953117 & 0.0000 \\
Perputaran Persedisan & 13547.19 & $\$ 28.7028$ & 16.34746 & 0.0000 \\
Perputaran Piutang & 134750.7 & 4060.700 & 33.18410 & 0.0000 \\
\hline
\end{tabular}

R-squared

Adjusted R-squuared

S.E. of regression

Sum squared resid

Log likelihood

F-statistic

Prob(F-atatistic)
0.977885 Mean dependent var

0.975334 S.D. dependent var

55072.48 Akake info criterion

$7 . \$ 9 \mathrm{E}+10$ Schwarz criterion

-367.913S Hannan-Quinn criter.

383.2306 Durbin-Watson stat

0.000000
249466.0

350656.9

24.79425

24.98108

24.85402

2.386147

\section{Sumber: Hasil Eviews 9/diolah sendiri (2017)}

Berdasarkan tabel 4.7 dengan menggunakan model common effect (CE), maka persamaan regresinya adalah:

Log_Tingkat Laba $=-436494.3-20423.43$ Perp. Kas + 13547.19 Perp.

Persediaan134750.7 Perp. Piutang. 


\section{Model Random Effect (RE) \\ Dampak Tingkat Laba Terhadap Harga Saham}

Cross-section random effects test equation:

Dependent Variable: Harga Saham

Method: Panel Least Squares

Date: $12 / 13 / 17$ Time: $02: 55$

Sample: 20112016

Periods included: 6

Cross-sections included: 5

Total panel (balanced) observations: 30

\begin{tabular}{lclll}
\hline \multicolumn{1}{c}{ Variable } & Coefficient & Std. Error & t-Statistic & Prob. \\
\hline \hline C C & 1.683780 & 0.279528 & 6.023657 & 0.0000 \\
\hline \multicolumn{5}{c}{ Effects Specification } \\
\hline \hline Cross-section fixed (dummy variables) & & \\
\hline R-squared & $5.29 E-06$ & $6.57 E-07$ & 8.049269 & 0.0000 \\
Adjusted R-squared & 0.729701 & Mean dependent var & 3.002765 \\
S.E. of regression & 0.673389 & S.D. dependent var & 2.170392 \\
Sum squared resid & 1.240376 & Akaike info criterion & 3.445563 \\
Log likelincod & 36.92480 & Schwarz criterion & 3.725803 \\
F-statistic & -45.68345 & Hannan-Quinn criter. & 3.535214 \\
Prob(F-statistic) & 12.95814 & Durbin-Watson stat & 2.407716 \\
\hline \hline
\end{tabular}

Sumber: Hasil Eviews 9/diolah sendiri (2017)

Berdasarkan tabel diatas dengan menggunakan model random effect (RE), maka persamaan regresinya adalah:

Log_Harga Saham $=1.683780+5.29 \mathrm{E}-06$ Tingkat Laba

Hasil Analisa Regresi Data Panel

Pengaruh Pengaruh Perputaran Kas, Perputaran Persediaan dan Perputaran Piutang terhadap Variabel Dependen Tingkat Laba

Cross-section random effects tert equation:

Dependent Variable. Tingkat Laba

Method: Panel Least Squares

Date: 12/417 Time: 20:26

Sample: 20112016

Periods included: 6

Cross-iections iscluded:

Total panel (balanced) observations: 30

\begin{tabular}{|c|c|c|c|c|}
\hline Variable & Coefficient & Std Enor & t-Statiatic & Prob. \\
\hline $\mathrm{c}$ & -4364943 & 39005,42 & -11.19060 & 0,0000 \\
\hline Pepputaras Kas & $-20423,43$ & 5166.410 & -3953117 & 0,0000 \\
\hline Perputaran Persedinan & 13547.19 & 328.7028 & 16.34746 & 0.0000 \\
\hline Perputaran Piutang & 134750.7 & 4060.700 & 33,18410 & 0.0000 \\
\hline$R$-squared & 0.977885 & \multicolumn{2}{|l|}{ Mean dependent var } & 249466.0 \\
\hline Adjusted R-sqquared & 0.975334 & \multicolumn{2}{|l|}{ S.D. dependent var } & 350656.9 \\
\hline SE of regresaica & 55072.48 & \multicolumn{2}{|l|}{ Akaike info criterion } & 24.79425 \\
\hline Stum squared recid & $7.89 \mathrm{E}+10$ & \multicolumn{2}{|l|}{ Schwarz criterion } & 24.98108 \\
\hline Log likelihood & -367.9138 & \multicolumn{2}{|l|}{ Hannsn-Quinn crites } & 24.85402 \\
\hline F-statiatic & 383.2306 & \multirow{2}{*}{\multicolumn{2}{|c|}{ Durbin-Watson stat }} & 2.386147 \\
\hline Prob(F-statintic) & 0.000000 & & & \\
\hline
\end{tabular}

Sumber: Hasil Eviews 9/diolah sendiri (2017) 
Setelah dilakukan pengujian regresi data panel pengaruh variabel (x) terhadap variabel (y) menggunakan program Eviews pada tabel diatas diperoleh $F$ hitung sebesar 383.2306 jika dibandingkan $F$ tabel pada tingkat $\alpha=5 \%$ dan $\mathrm{df}=(\mathrm{k}-1)=(3-1)=2$ dan $\mathrm{df} 2=(\mathrm{n}-\mathrm{k})=(30-3)=27$ diperoleh angka sebesar 3.35.

Jika dilihat perbandingan antara $\mathrm{F}$ hitung dan $\mathrm{F}$ tabel pada regresi data panel yang diolah menggunakan program Eviews diatas tersebut diperoleh hasil jika F hitung lebih besar dari pada F tabel, selanjutnya jika dilihat dari probabilitas nilainya sebesar 0.00 dan nilai ini lebih kecil dari nilai tingkat signifikansi sebesar 0.05. Hal ini bisa diartikan jika variabel independen secara simultan memiliki pengaruh terhadap variabel dependen.

Kesimpulan analisis hipotesis pertama dalam penelitian ini adalah variable perputaran kassecara signifikan berpengaruh negative terhadaptingkat labadisebabkan karena tingkat laba pada tahun 2014 sampai dengan 2016 perusahaan otomotifrata- rata terjadi penurunan,bahkan ada sebagian yang mengalami kerugian.Kesimpulan analisis hipotesis kedua yakni perputaran persediaan berpengaruh signifikan tingkat laba.perputaran piutang dapat mempengaruhi tingkat laba disebabkan karena Perputaran piutang pada perusahaan otomotif ini stabil. Sedangkan kesimpulan hipotesi ketiga perputaran piutang berpengaruh signifikan tingkat laba disebabkan karena perputaran piutang pada perusahaan otomotif ini stabil, pada situasi seprti ini bisa dijadikan gambaran atau tolak ukur jika manajemen atau sistem pengendalian piutang pada perusahaan otomotif cukup bagus. 


\section{Model Common Effect (CE) Dampak Tingkat Laba Terhadap Harga Saham}

Dependent Variable: Harga Saham

Method: Panel Least Squares

Date: $12 / 13 / 17$ Time: 02.50

Sample: 20112016

Periods included: 6

Cross-sections included: 5

Total panel (balanced) observations: 30

\begin{tabular}{lrlll}
\hline \multicolumn{1}{c}{ Variable } & Coefficient & Std. Error & t-Statistic & Prob. \\
\hline \multicolumn{1}{c}{ C } & 1.683780 & 0.258793 & 6.506293 & 0.0000 \\
\multicolumn{1}{c}{ Tingkat Laba } & $5.29 E-06$ & $6.08 E-07$ & 8.694204 & 0.0000 \\
\hline \hline R-squared & 0.729701 & Mean dependent var & 3.002765 \\
Adjusted R-squared & 0.720048 & S.D. dependent var & 2.170392 \\
S.E. of regression & 1.148365 & Akaike info criterion & 3.178896 \\
Sum squared resid & 36.92480 & Schwarz criterion & 3.272310 \\
Log likelihood & -45.68345 & Hannan-Quinn criter. & 3.208780 \\
F-statistic & 75.58918 & Durbin-Watson stat & 2.407716 \\
Prob(F-statistic) & 0.000000 & & & \\
\hline
\end{tabular}

Sumber: Hasil Eviews 9/diolah sendiri (2017)

Berdasarkan tabel diatas dengan menggunakan model common effect (CE), maka persamaan regresinya adalah:

Log_Harga Saham $=1.683780+5.29$ E-06 Tingkat Laba.

\section{Hasil Analisa Regresi Data Panel Dampak Tingkat Laba terhadap Harga Saham}

Cross-section random effects test equation:

Dependent Variabie: Harga Saham

Method: Panel Least Squares

Date: $12 / 13 / 17$ Time: 03:33

Sample: 20112016

Periods included: 6

\begin{tabular}{lrlll}
\hline \hline \multicolumn{1}{c}{ Variable } & Coefficient & Std. Error & t-Statistic & Prob. \\
\hline \hline \multicolumn{1}{c}{ C } & 1.683780 & 0.258793 & 6.506293 & 0.0000 \\
\multicolumn{1}{c}{ Tingkat Laba } & $5.29 \mathrm{E}-06$ & $6.08 \mathrm{E}-07$ & $\mathbf{8 . 6 9 4 2 0 4}$ & 0.0000 \\
\hline \hline R-squared & 0.729701 & Mean dependent var & 3.002765 \\
Adjusted R-squared & 0.720048 & S.D. dependent var & 2.170392 \\
S.E. of regression & 1.148365 & Akaike info criterion & 3.178896 \\
Sum squared resid & 36.92480 & Schwarz criterion & 3.272310 \\
Log likelihood & -45.68345 & Hannan-Quinn criter. & 3.208780 \\
F-statistic & 75.58918 & Durbin-Watson stat & 2.407716 \\
Prob(F-statistic) & 0.000000 & & \\
\hline \hline
\end{tabular}

Sumber: Hasil Eviews 9/diolah sendiri (2017) 
Berdasarkan Tabel diatas, yang dioalah menggunakan program Eviewssecara parsial diperoleh nilai T hitung variabel independen struktur tingkat laba adalah 8.694204, tanda positif artinya memiliki hubungan positif. Sedangkan nilai $\mathrm{T}$ tabel dengan timgkat $\alpha=5 \%$ dan $\mathrm{df}=(\mathrm{n}-\mathrm{k})$ adalah $\mathrm{df}=(30-3)=27$, maka Ttabel $(0.05 ; 27)=1.70329 \mathrm{dan}$ itu berarti nilaiT hitung lebih besar dari pada $\mathrm{T}$ tabel $(8.694204$ >1.70329)dengan demikian dapat diambil kesimpulan jika tingkat laba memiliki dampak signifikan terhadap harga saham. Kemudian nilai probabilitas tingkat laba lebih kecil dari $\alpha=0.05(0.0000<0.05)$ dengan demikian bisa diambil kesimpulan jika variabel tingkat laba berpengaruh secara signifikan terhadap harga saham.

\section{SIMPULAN}

Setelah dilakukan pengujian dan pengolahan data mengunakan program Eviews pada penelitian ini mengenai "Analisis Pengaruh Perputaran Kas, Perputaran Persediaan, Perputaran Piutang terhadap Tingkat Laba serta dampaknya terhadap Harga Sahampada perusahaan otomotif yang terdaftar Malaysia Exchange Stock dari tahun 2011 hingga 2016”. Setelah penulis melakukan pengumpulan, pengolahan dan analisis data, maka dapat diperoleh kesimpulan bahwa nilai t-hitung variabel perputaran kas> t-tabel ($3,953117>1.68195)$, tanda negatif artinya memiliki hubungan negative atau berbanding terbalik.Dengan demikian berartivariabel perputaran kas secara signifikan berpengaruh negative terhadap tingkat laba.

Selanjutnya dari pengolahan data tersebut juga didapat nilai t-hitung variabel perputaran persediaan> t-tabel $(16.34746>1.70329)$,dan nilai t-hitung variabel perputaran piutang $>$ t-tabel $(33.18410>1.70329)$. melihat hasil dari pengolahan tersebut dapat diambil kesimpulan bahwa variabel perputaran persediaan dan variabel perputaran piutang berpengaruh postif signifikan terhadaptingkat laba.

Dan selanjutnya dari pengolahan data terasebut diperoleh hasil penelitian jika nilai f-hitung variable $(\mathrm{X})$ yang terdiri dari "perputaran kas, perputaran persediaan, perputaran piutang" lebih besar dari nilai t-tabel (383.2306> 3.35). 
Hal ini berarti bahwa variabel $(\mathrm{X})$ yang terdiri dari "perputaran kas, perputaran persediaan, perputaran piutang" secara simultan mempunyai pengaruh yang signifikan terhadap tingkat laba. Dan yang terakhir pada pengolahan data tersebut di peroleh nilai t-hitung variabel tingkat laba lebih besar dari pada nilai t-tabel (8.694204 >1.70329), dengan demikian dapat diambil kesimpulannya bahwa variablel tingkat laba berdampak signifikan terhadap harga saham.

\section{REFRENSI}

Ade Gunawan dan Sri Fitri Wahyuni 2013. "Pengaruh rasio keuangan terhadap pertumbuhan laba pada perusahaan perdagangan di Indonesia". "Jurnal Manajemen \& Bisnis Vol. 13 No. 01/ Universitas Muhammadiyah Sumatra Utara".

Amirullah, Haris Budiyono. 2014. Pengantar Manajemen Edisi 2. Yogyakarta : Graha Ilmu.

Anshori, M. dan S. Irawati. 2009. “Metodologi Penelitian Kuantitatif”. Airlangga University Press (AUP). Surabaya.

Erfaweny, Lirna. 2009. "Pengaruh Penggunaan Komponen Modal Kerja Terhadap

Profitabilitas pada PT. Indofood Sukses Makmur", diakses 10 Oktober 2015.

Dewi Priyatno, 2008, "Mandiri Belajar SPSS - Bagi Mahasiswa dan Umum”. Yogyakarta: MediaKom

Fadliyan Ahmad, S. Murni dan Yunita M. 2014. "Perputaran Piutang, Perputaran Persediaan dan Struktur Modal Terhadap Laba Per Lembar Saham Pada Industri Semen Yang Go Public di BEI”. Jurnal EMBA Vol. 2. No. 2. Universitas Sam Ratu Langi Manado.

Fahmi, irham hadi . 2011. “Analisis Laporan keuangan”. Bandung: Alfabeta.

Ghozali, Imam. 2011. “Aplikasi Analisis Multivariate Dengan Program SPSS”.Badan Penerbit Universitas Diponegoro Semarang.

Griffin, Ricky W. 2004. “Manajemen”; edisi ketujuh jilid 2. Jakarta: Erlangga. 
Halimatus Sa' diyah. 2014. "Pengaruh Laba Bersih Terhadap Harga Saham Pada Perusahaan Manufaktur Barang dan Konsumsi yang terdaftar di Bursa Efek Indonesia”. Jakarta. Universitas Muhammadiyah Jakarta.

Handoko, T. Hani. 2009. “Manajemen”. Yogyakarta: BPFE-YOGYAKARTA.

Hessel Nogi S Tangkilisan. 2003. "Manajemen Modern Untuk Sektor Publik". Yogyakarta: Balairung

Ikatan Akuntan Indonesia. "Standar Akuntansi Keuangan per Efektif 1 Januari 2015". Jakarta, 2014.

J. Supranto. 2001. "Statistik Teori dan Aplikasi”. Edisi 6. Jakarta:Erlangga.

Jonathan Sarwono, Hendra N. S. 2014 "Eviews: Cara Operasi dan Prosedur Analisis”. Jakarta: Andi Publisher

Jumingan. 2009. “Analisis Sumber dan Penggunaan Modal Kerja”. Jakarta: Bumi Aksara 2006. “Analisis Laporan Keuangan”. Jakarta: PT. Bumi Aksara.

Kasmir. 2008. “Analisis Laporan Keuangan”. Jakarta: PT. Raja Grafindo. 50 . 2010. “Pengantar Manajemen Keuangan”. Edisi Pertama. Cetakan Kedua. Jakarta: Kencana Prenada Media Group

Lailan Paradiba, Karlota Nainggolan. "Pengaruh Laba Bersih Operasi Terhada HargaSaham Pada Perusahaan Food and Beverage yang Terdaftar di Bursa Efek Indonesia”. Jurnal Riset Akuntansi dan Bisnis Vol. 15 No. 1/ 2015 Universitas Medan Area.

Limas Guntur Anggriono Putra. 2014. "Pengaruh Penjualan dan Perputaran Piutang Terhadap Laba Bersih Perusahaan Farmasi” Jurnal Ilmu \& Riset Manajemen Vol.3 No. 1 (2014). Sekolah Tinggi Ilmu Ekonomi Indonesia Surabaya.

Longenecker, Justin G, 2001. “Kewirausahaan: Manajemen Usaha Kecil”. Edisi Pertama - Jakarta: Salemba Empat.

Martono dan Agus Harjito. 2010. “Manajemen Keuangan”. Edisi ke 3. Jakarta : Ekonisia. 
Nurul Widyawati. 2014. "Pengaruh Penjualan Dan Perputaran Piutang Terhadap Laba Bersih pada Perusahaan Farmasi”. Jurnal Ilmu \& Riset Manajemen Vol. 3 No. 1. Sekolah Tinggi Ilmu Ekonomi Indonesia Surabaya.

Olivia Mada Rolos, Sri Murni, Ivvone S. Saerang. 2014. "Modal Kerja Pengaruhnya Terhadap Net Profit Margin Pada Perusahaan Tambang yang Terdaftar di Bursa Efek Iindonesia”. Jurnal EMBA Vol. 2 No. 2 Juni 2014. Universitas Sam Ratu Langi Manado

Raharjaputra (2009). "Manajemen Keuangan dan Akuntansi untuk Eksekutif Perusahaan”. Jakarta: Penerbit Salemba Empat.

Samsul, Mohammad. 2006. “Pasar Modal dan Manajemen Portofolio”.Jakarta : Erlangga.

Sutrisno. 2009. "Manajemen Keuangan Teori, Konsep dan Aplikasi”. Edisi Pertama. Cetakan Kedua. Yogyakarta: Ekonisia.

Subramanyam dan Wild. 2010. “Analisis Laporan Keuangan”. Edisi Kesepuluh. Jakarta: Salemba Empat.

Van horne James C \& Jhon M. Wachowicz. 2005. "Fundamental of Financial Management/Prinsip-prinsip Manajemen Keuangan”. (Edisi Kedua belas). Jakarta: Salemba Empat. 